\title{
ECONOMIC ANALYSIS OF THE INFLUENCE OF MILK MARKET CONCENTRATION ON PROCUREMENT EFFICIENCY IN THE DEFENSE SYSTEM
}

\author{
Milan Mihajlovićc 1 Snežana Krstič́2, Slobodan Šegrt ${ }^{3}$, Dragana Pavlovic $^{4}$, \\ Duško Jovanovičc ${ }^{5}$ Tihomir Simeunovićc
}

\begin{abstract}
Summary
Increasing efficiency during realization of procurements in the defence system imposes the requirement to analyse the market, in order to detect all of its characteristics and to make conclusions which would benefit during planning of budgetary assets by one comprehensive process. Procuring milk and milk products represents a significant part of defence system's procurements which represents that a significant segment of the consumer standard of the Serbian Army, which implies the interest of authors to point to the significance of the concentration of the supply branch on the realization of procurements on the example of this market. The aim of this paper is to display the state and actual trends on the market of production and processing of milk, define methodological framework and point to the intensity and terms of competition and their influence on procurement criteria, especially price in the defence system of the Republic of Serbia.
\end{abstract}

Key words: economic analysis, concentration, milk market, procurements, defence system.

JEL: $D 43, Q 13$.

1 Milan Mihajlović, M.A., Military Academy, University of Defence, Military Academy, Belgrade, Pavla Jurišića Šturma 33, 11000 Belgrade, Serbia, Phone: +381 64302 1951, E-mail: milan.mih83@gmail.com

2 Snežana Krstić, Ph.D., Assistant Professor, University of Defence, Military Academy, Belgrade, Pavla Jurišića Šturma 33, 11000 Belgrade, Serbia.

3 Slobodan Šegrt, Ph.D., Assistant Professor, School of economics and managament studies, Karađorđeva Street no. 52, 34000 Kragujevac, Serbia.

4 Dragana Pavlović, M.A., Faculty of Sport and Physical Education, Belgrade, Blagoja Parovića 156, 11000 Belgrade, Serbia.

5 Duško Jovanović, Ph.D., Assistant Professor, School of economics and managament studies, Karađorđeva Street no. 52, 34000 Kragujevac, Serbia.

6 Tihomir Simeunović, Ph.D., Assistant Professor, School of economics and managament studies, Karađorđeva Street no. 52, 34000 Kragujevac, Serbia.

EP 2016 (63) 3 (973-985) 


\section{Introduction}

Dynamic conditions on today's global market, impose the need for continuous research in order to get information on necessary parameters that relate to characteristics on market structure and competition intensity. In economically developed countries the level of market concentration represents one of best known and most commonly used indicators of a company's monopoly power on the observed market. Behaviour of economic subjects and their relation to consumers can best be viewed by monitoring the market concentration level. In case of high concentration and a very limited market the choice of consumers is highly reduced. Upbringing of modern market structure for securing intensive and effective competition between economic subjects is an imperative of every country, especially developing ones.

Having in mind the significance of the milk and milk products industry on the life standard of citizens, activities of companies in this industry are from time to time under review by public opinion and regulatory bodies in the area of competition protection.

Procurement initiators in the Serbian Army examine and explore the market of each singular procurement item by: examining the market development level, comparing prices of multiple potential suppliers, monitor the quality, guaranty period, method and expenses of the item's life cycle, delivery deadlines, existing regulations and standards, possibilities to satisfy the needs of the procurer in another way on the market etc.

\section{The literature review}

Large number of different factors that act on the market position of economic subjects which can be tied, for both supply and demand segment, so they condition for the market to exert itself as a dynamic and insufficiently stable system. Side effects of such state are: unsteady rate of economic growth and cyclicality of economic development; insufficient utilization of resources; instability of prices; appearance of inflation and unemployment.

Deviation from perfectly competitive market means the state of disrupting optimal allocation of resources, understood in Pareto way. Pareto optimum implies that "distribution is optimal if it is such that every improvement of the situation of ones causes deterioration of the situation of the others. Put differently, distribution is optimal in Pareto way only if there isn't any change which can improve a situation of ones without harm to others (Gould, Ferguson, 1984).“ Pareto efficiency in production implies equality of marginal utility of production factors, and in consumption the situation in which the relation between marginal usefulness and price is equal for all goods used. American Nobel Prize winner Joseph Stiglitz quotes sight important market imperfections that point to the imperfection of the market and deviation from Pareto efficiency (Stiglitz, 2013): incomplete (imperfect competition), external effects, public goods, imperfect information, incomplete market, unemployment and other macroeconomic disorders.

All stated deviations from Pareto market efficiency significantly influence the Serbian Army, as the user of budgetary assets, which exerts those aspects of imperfection in terms 
of reducing approved financial assets and reducing consumption efficiency of budgetary assets, usually through problems in realizing public procurements.

The way that market mechanism functions, as well as positive and negative influences of that functioning on total economic and social trends, importantly depend on existing market forms, i.e. market morphology. Market structure significantly influences the trading conditions, forming of prices, behaviour of economic subject, primarily producers and sellers, but also consumers and buyers. Free functioning of market forces - competition depends on market structures (Lipczynski, Wilson, 2001; Ezekiel, 2012). Efficient regulation of market relations assumes knowledge of their structure, especially if those structures carry the characteristic of a monopoly or oligopoly.

In economically developed countries the level of market concentration represents one of most known and most frequently used indicators of monopoly power of a company on the observed market. Behaviour of economic subjects and their relations to consumers can best be viewed by tracking the market concentration level.

During determination of supply concentration level, market participation of certain individuals is used. Certain companies continually strive to increase their market participation, because there is a positive correlation between market participation and profitability. The aim to achieve greater market influence has the consequence of greater supply concentration level (Amato, Wilder, 2004).

During the study of the supply concentration level on a relevant market it is necessary two problems. First is choosing the relevant market on which supply concentration will be measured, and the other is the choice of variable over which the concentration level will be measured (Stojanović, Radivojević, 2008).

Concept of a relevant market deviates from a common understanding of the concept of a market in practice and economic theory. It has its two aspects - material and geographical. Relevant market includes relevant market of products and a relevant geographical market. Therefore, the market must be determined by the type of products (goods and services) sold on it, and bounded by the area on which they are bought and sold (Labus, 2008). Our law accepts the definition of relevant market that exists in the European Union. Relevant product market is a sum of products which are replaceable to consumers under acceptable conditions, especially on the basis of their properties, common purpose and price. Relevant geographical market is the territory on which market subjects participate in supply and demand on equal competition conditions, which differ from neighbouring territories (Law on competition protection, 2013).

The other problem while measuring concentration is the choice of suiting variable over which concentration is measured. Amongst variables used for that purpose are: total production, traffic, total assets, number of employees, revenue etc. Each of these variables carries certain limitations with it, so the concentration grade determined by its usage demands high level of analytics and researchers subjective assessments in order for the results to be understandable and applicable. 
Having in mind the significance of producing raw milk and its processing in drinking milk and milk products, as well as its total established state of facts, and especially the structure of certain markets in production and processing cycle in this sector by conducting the analysis of state of competition on the market where raw cow's milk is bought and production and processing of milk and milk products, certain indicators should be obtain which will be used in measuring the concentration of the supply side of this branch.

Mitrović, Knežević, Veličković (2015) point that observing the milk production in the Republic of Serbia, also from 2009 to 2013, there was a downward trend in milk production in million liters from year to year, except in 2012, when the milk production compared to the year 2011 increased by 8 mill. litres The small farmers participate significantly in the total cow milk production in Serbia and their dominant position is a result of declining farms (Drašković, Rajković, Kostić, 2010).

Contrary to the milk production industry, the milk processing industry in Serbia is mainly concentrated in bigger capacities. These capacities have been recently privatized and modernized and dominate the domestic market with more than $90 \%$ of overall processing capacities in Serbia. Production of these processing capacities is mostly oriented toward liquid dairy products, while cheese production is mainly of less priority. On the other hand, there are a large number of small milk processing production facilities that cover $4-6 \%$ of overall capacities (there are over two hundred registered dairies in Serbia, but not all of them are active - most of them are dairies of medium and small capacity). Such dairy facilities mainly operate locally, and they are especially interested in production of cheese, spreads and other fermented milk products. In Serbia although purchase is growing, number of producers who deliver milk reduces. Therefore, it implies a trend of strengthening marketoriented farmers in Serbia (Zekić, Mijić, Jakšić, Milenković, 2016).

\section{Methodology of measuring market concentration}

The aim of this paper is to highlight the current trends on the milk and milk products market and point to the significance of determining the market structure through market structure, for more efficient realization of procurements and spending appropriation allocated budgetary assets in the defence system. The research subject is the economic analysis of the milk production market of the Republic of Serbia in order for the analysis of the given data on the market structure to influence the efficiency of the realised procurements for the defence system.

Getting information on a specific industry and its structure, economic researchers and economic decision makers use for different concentration indicators. As such, they are used for measuring the supply concentration level, but also for understanding the nature of competition between companies on a specific market in a certain moment in time. Between a large number of indicators for determining, i.e. measuring inequality level of participation of certain participants in a market structure, most often used ones are: Concentration ration of leading companies $\mathrm{n}(\mathrm{CRn})$, Herfindal-Hirschman index (HHI), Lorenz curve (concentration curve), Gini coefficient and Entropy index (Mikhalkina, Maitah, Šrédl, 
2015). Application of these indicators relates to understanding, considering and analysing the existence or nonexistence of monopolistic market structure.

Many markets have shown the existence of a high level of correlation between specific concentration indicators. However, none of them can show the real nature of competition of a branch on its own. Theorists Hannah and Kay gave criteria which a certain indicator needs to satisfy in order to completely describe the concentration and nature of competition in a branch (Kostić, 2008).

- Concentration indicator needs one industry to classify in a more concentrated one when the participation sum of biggest production and sale companies exceeds that sum in the other;

- Market share transfer from small to big companies should bring to an increase in concentration. Also, entrance of new companies in a branch should reduce, and exit increase concentration;

- Connecting companies within each branch should increase the branch concentration level;

- If the chance for growth in a certain period are identical from big and small companies, effect of increasing will be far larger from bigger than for smaller companies, which would lead to an increase in concentration level.

According to mentioned criteria the biggest analytical significance is had by HerfindalHirschman coefficient which largely satisfies the stated criteria.

This index represents a convex function of market shares, and is therefore sensitive to their inequality. He represents a sum of squares of individual market shares of a company in one industry. It can be expressed through the following equation:

$$
H H I=\sum_{i=1}^{n} X_{i}^{2}
$$

Where $X_{i}$ is the market share of $i$ company (Šaj, 2005).

The significance of the index can be viewed in the fact that even though it respects individual market shares of all companies in a branch it still reacts to the presence of a company with great market share, which significantly increases its value (Mihajlović, 2016).

Unlike the concentration ration of $\mathrm{n}$ leading companies, the value of Herfindahl-Hirschman index depends on the number of competitors on the market, and unlike its relevant market strength. The value of HHI is reduced with an increase in the number of competitors on the market. Also the value of this index grows with an increase of differentiation in market power size because large companies have the largest ponder in the calculation due to effect of squaring market shares. The biggest problem in determining the value of HerfindalHirschman index is the necessity of owning information on the value of market shares for each company that belongs to the observed market. From the formula that calculates 
the Herfindal-Hirschman index it can be observed that companies with small market share value have a very small influence on the result. That is, for calculating the value of Herfindal-Hirschman index it is necessary to own data regarding market share of all companies whose market share greater than 1\%.(Zhou, Gao, Yang, Zhou, 2005)

When the values of this index are calculated the market is classified as (Šaj, 2005; Dobre 2009):

- Un-concentrated - when HHI is bellow $15 \%$;

- Moderately concentrated - when $\mathrm{HHI}$ is between $15 \%$ and $25 \%$ and

- Highly concentrated - when HHI is above $25 \%$.

Sectoral analysis of the state of competition in the dairy sector, which includes the purchase of raw cow's milk, production and processing of milk and milk products, wholesale and retail sale of milk and milk products was conducted from January 2014 until the end of July 2015. The production-processing cycle was included, i.e. purchase of raw cow's milk and production and processing of milk and milk products. Other types of milk (sheep, goat, etc.) weren't the subject of this analysis due to their extremely low representation of around $2 \%$ of the total amounts of milk produced in the Republic of Serbia.

With the goal of acquiring data and information necessary for the realization of sectoral analysis to the participants on the market of purchase, production and processing of milk and milk products, a choice of dairies has been made based on the following criteria: significance of certain participants on a purchase of raw milk market, installed production capacities and their position on regional market segments of producing and processing milk and milk products.

For the needs of research, concentration effects must be examined on the following relevant product markets: market for purchase of raw milk intended for further industrial processing; market for producing milk and milk products; market for selling milk and milk products.

According to the data from the Republic institute for statistics (available at: www.stat. gov.rs), dairies have purchased and processed around 818,000,000 litres of raw milk from primary milk producers in 2014 , which is the data on aggregate size of the market for purchase of raw milk intended for further industrial processing in dairies that buy it. Based on the data from Ministry of agriculture and environmental protection, there are 202 dairies in Serbia, but actively around 120, taking into consideration that the number of active dairies varies from 120 to 140 , depending on the year.

Table 1. Comparative review of yearly production of raw milk

\begin{tabular}{|l|c|c|c|}
\hline \multirow{2}{*}{ Type of milk } & \multicolumn{3}{|c|}{ Milk production (in thousands of liters) } \\
\cline { 2 - 4 } & $\mathbf{2 0 1 2 .}$ & $\mathbf{2 0 1 3 .}$ & $\mathbf{2 0 1 4 .}$ \\
\hline Cow's & $1,465,000$ & $1,451,000$ & $1,492,000$ \\
\hline
\end{tabular}

Source: Ministry of agriculture and environmental protection (available at: www.mpzzs.gov.rs); 
Table 2. Amount of bought and processed cow's milk

\begin{tabular}{|c|c|c|c|}
\hline \multirow[t]{2}{*}{ Type of milk } & \multicolumn{3}{|c|}{$\begin{array}{c}\text { Amount of bought and processed cow's milk (in } \\
\text { thousands of litres) }\end{array}$} \\
\hline & 2012. & 2013. & 2014. \\
\hline Cow's & 712,000 & 745,000 & 818,000 \\
\hline
\end{tabular}

Source: Ministry of agriculture and environmental protection (available at: www.mpzzs.gov.rs);

Data from previous tables point to the conclusion that in the observed and graded period, the amounts of produced primary milk were pretty stable and balanced. This type of qualification comes from the fact that yearly changes in those amounts varied between $1 \%$ and $2 \%$ (this production was greater in 2014 for $1.8 \%$ than comparative production in 2012). Changes on the side of purchased amounts of raw milk that dairies processed were far more intensive. That purchase in 2014 was 106 million or $14.9 \%$ greater than the purchased amount in 2012. That has further opted a positive tendency which relates to the growth of participation of purchased milk by dairies in total produced raw milk, which can be seen in table 3 .

Table 3. Amount of purchased raw cow's milk intended for further processing and market shares of dairies, 2014

\begin{tabular}{|r|l|r|r|}
\hline No. & Participant on the market & $\begin{array}{r}\text { Amount of purchased raw } \\
\text { milk (in thousands of litres) }\end{array}$ & Participation (in \%) \\
\hline 1 & Imlek & {$[\ldots]$} & $/ 30-40 /$ \\
\hline 2 & Somboled & {$[\ldots]$} & $/ 5-10 /$ \\
\hline 3 & Mlekara Šabac & $41,229.03$ & 5.0 \\
\hline 4 & Mlekoprodukt & $34,071.68$ & 4.2 \\
\hline 5 & Niška mlekara & {$[\ldots]$} & $/ 0-5 /$ \\
\hline 6 & Meggle Srbija & {$[\ldots]$} & $/ 0-5 /$ \\
\hline 7 & Granice & {$[\ldots]$} & $/ 0-5 /$ \\
\hline 8 & KUČ-COMPANY & $21,074.31$ & 2.6 \\
\hline 9 & Lazar & $20,441.18$ & 2.5 \\
\hline 10 & Ekomlek & $14,366.51$ & 1.8 \\
\hline 11 & Mlekara Leskovac & $13,883.53$ & 1.7 \\
\hline 12 & MLINPEK/МILK & 910.00 & 0.1 \\
\hline 13 & Total & $572,869.08$ & 70.0 \\
\hline 14 & Other (110 млекара) & $245,130.92$ & 30.0 \\
\hline 15 & TOTAL & 818.000 .00 & 100.0 \\
\hline
\end{tabular}

Source: Commission for protecting competition (available at: www.kzk.org.rs)

Contents of the previous table confirm adequate choice of surveyed dairies, since 12 chosen dairies participate with $70 \%$ of the total amount of purchased raw milk.

Based on the data from the table in can be concluded that participation of the company "Imlek" in the market for purchase of raw milk in the Republic of Serbia is $/ 30-40 / \%$, "Niška mlekara" $/ 0-5 \%$, dairy "Somboled" has the participation of $/ 5-10 / \%$, "Mlekara Šabac" - 5\%, "Mlekoprodukt" - 4.2\%, "MEGGLE SRBIJA”- /0-5/\%, dairy ,Granice“ - /0-5/\%, ,KUČ- 
COMPANY“ - 2.6\%, dairy „Lazar“ - 2.5\%, „Ekomlek“ - 1.8\%, ,Mlekara Leskovac“ $1.7 \%$, and ,MLINPEKMILK“" $-0.1 \%$.

Analysing the effects of concentration on the market for purchase of raw cow's milk in the Republic of Serbia, firstly the structure of the relevant market was analysed, market shares of participants on a market, as well as real and potential competitors. It is evident that "Imlek" has undoubtedly a leading role and represents a leader in this market with a share on this relevant market (/30-40/\%). All remaining competitors (dairies) have significantly smaller market shares from "Imlek" so the second participant on this market - dairy "Somboled" has a share of $/ 5-10 / \%$. There isn't any other competitor that has a significant share. They are dairies of local, i.e. regional significance, out of which none performs a significant competitive pressure on "Imlek".

Table 4. Market concentration level measured by HHI

\begin{tabular}{|c|c|c|c|c|}
\hline No. & $\begin{array}{c}\text { Participant on the } \\
\text { market }\end{array}$ & $\begin{array}{c}\text { Amounts of } \\
\text { purchased raw milk } \\
\text { (in thousands of } \\
\text { litres) }\end{array}$ & Participation (in \%) & HHI \\
\hline 1 & Imlek & {$[\ldots]$} & $/ 30-40 /$ & {$[\ldots]$} \\
\hline 2 & Somboled & {$[\ldots]$} & $\mid 5-10 /$ & {$[\ldots]$} \\
\hline 3 & Mlekara Šabac & $41,229.03$ & 5.0 & 25.4 \\
\hline 4 & Mlekoprodukt & $34,071.68$ & 4.2 & 17.3 \\
\hline 5 & Niška mlekara & {$[\ldots]$} & $/ 0-5 /$ & {$[\ldots]$} \\
\hline 6 & Meggle Srbija & {$[\ldots]$} & $/ 0-5 /$ & {$[\ldots]$} \\
\hline 7 & Granice & {$[\ldots]$} & $/ 0-5 /$ & {$[\ldots]$} \\
\hline 8 & KUČ-COMPANY & $21,074.31$ & 2.6 & 6.6 \\
\hline 9 & Lazar & $20,441.18$ & 2.5 & 6.2 \\
\hline 10 & Ekomlek & $14,366.51$ & 1.8 & 3.1 \\
\hline 11 & Mlekara Leskovac & $13,883.53$ & 1.7 & 2.9 \\
\hline 12 & MLINPEK/MILK & 910.00 & 0.1 & 0.0 \\
\hline 13 & Total & $572,869.08$ & 70.0 & \\
\hline 14 & Other (110 dairies) & $245,130.92$ & 30.0 & 8.2 \\
\hline 15 & Total & $818,000.00$ & 100.0 & 1.575 \\
\hline
\end{tabular}

Source: Commission for protecting competition (available at: www.kzk.org.rs)

Based on previously stated data (table 4) Herfindahl and Hirschman's index (HHI) was calculated. According to this indicator the market for purchasing raw milk in the Republic of Serbia can be considered moderately concentrated, because the analysis pointed that HHI was 1.575 before conducting concentration.

\section{Influence of the market structure on the realization of milk procurement in the defence system}

Procurement function (Milojević, Vukoje, Mihajlović, 2013) is by its nature, very complex and comprehensive industry with material and financial operating of the defence system. It includes a wide spectrum of activities, ties and relations, starting from planning assets and 
procurements, to researching the market and conducting the very procurement.

Researching efficiency is essential for every industry, and with that Serbian Army, because it contains and links the goals of that industry within it, resources and transforms the processes which represent the basis for realizing goals. Considering efficiency of the procurement function in the Serbian Army can't be abstracted from the influence and other functions in the defence system (planning and approving funds, planning procurements and execution of financing), because they are preconditions for realizing public procurements. It also can't be abstracted in relation to economic movements, and especially tracking and adjusting to modern market movements.

Timely procurement of movable property is very significant for regular life and training of the Serbian Army. In order to procure assets from the domain of "regular industries" (food, clothes, energy, fuel, medicine, consumables and the like) significant assets are approved in the yearly expenditure. In relation to this, a market analysis of purchase raw cow's milk and producing and processing milk and milk products which has a significance for bodies that perform procurements in the defence system was performed, because the market structure significantly influences the efficiency of realization of procurements.

For the purpose of conducting procurements an economic analysis is conducted, which contains: the name, amount and estimated individual and total cost; data on companies from which procurements can be performed; a proposal on the method and concept of performing procurements; the name of the purchasing body for realizing procurements; data on whether movable property that are procured are adopted in equipment and weapons etc. (available at: www.mod.gov.rs). Depending on the type of procurement, next to these basic elements of analysis, special data is used as well, as follows: possibility of a procurement, production perspective, tendencies on the market, possibility of procuring spare parts etc. Dominant place within economic analysis of procurements in the Serbian Army is had by the following criteria elements: purchase price, quality, warranty periods and security of supply. The choice between submitted offers, in the Serbian Army very often in practice is done by applying criteria of lowest offered price, which is taken as deciding criterion, if all of the conditions put in bidding documents are met, before all defined demand for quality etc. (Law on public procurements, 2015).

Analysis of prices formed under the influence of market mechanism, i.e. law of supply and demand is significantly complex (Milosavljević, 2001). It's known that large procurements respond producers-suppliers, because it accelerates the turnover of its assets and reduces production and transport costs. Likewise enlargement of procurements for the Serbian Army provides higher benefits and total economic effects. It should also be had in mind that the price is an instrument of trade marketing and element of marketing mix, therefore the supplier puts an important accent on forming prices as well.

If the frame of freedom for forming prices by the suppliers and bidders is larger, i.e. if it is about an imperfect market (monopoly or oligopoly) the procurement process that the Serbian Military implements is that more complex. On the other side, there are products and goods (for example medicine) whose price is minimized by regulations of the Serbian 
government. In that case companies choose a strategy of renouncing margin and trying to increase earnings through an increase in turnovers, where the Serbian Army appears as a great spender (Krstić, Krstić, 2016).

However, sales and margins are mutually conditioned and a company usually asks a price that maximizes gain, using sales and margin as variables, in order to reach such price. The aim is to maximize total gain, not gain per unit.

Having in mind the aforementioned, based on the data on realized milk procurements and milk products in the defence system of the Republic of Serbia, in the research period of the market of purchasing raw cow's milk and producing and processing milk and milk products, it can be concluded that the most favourable bidder is the one offering the lowest price of previously mentioned "Imlek" products. Estimating the economic and financial strength of "Imlek", analysing the achieved revenue (Vukoje, 2013) of "Imlek", according to the data from public announced consolidated financial report for 2014 (available at: www.apr.gov.rs), its revenue is around 44.7 billion dinars, which is multiple times larger than the revenue of "Somboled", the next market participant, which according to the data from regular annual financial report from 2014 is 6.2 billion dinars. "Imlek" which is vertically integrated company, because it deals with purchase of raw milk, production of milk and milk products and selling milk and milk products, in this way more significantly does business on the market of the Republic of Serbia which allows it large possibility of reducing prices of offered products when it competes in procurement procedures.

"Imlek" has a large advantage in approaching supply and distribution markets, seeing as how it buys raw milk on almost the entire territory of the Republic of Serbia, which is a significantly larger part of the territory than the territory from which other dairies buy their raw milk in Serbia. For example, the next market participant "Somboled" buys its milk from far less places. Having in mind the strength of "Imlek's" suppliers and the market of raw milk purchase which is characterized by fragmented, atomized market structure and very low level of market concentration it can be said that it has a monopoly position which can be used for increasing profits.

\section{Conclusion}

On the example of the market for purchase of raw cow's milk and producing and processing milk and milk producing, this paper points a market movement trend of this branch and gives methodological basis for performing an analysis of this market by using a relevant market. Having in mind the significance of this industry for the defence system, as well as the life standard of citizens it isn't unusual that the activities in this industry are from time to time under review by public opinion and regulatory bodies in the area of protecting competition. With the goal of applying the methodology for measuring the concentration level on the market, it is necessary, as it is stated in the paper, to define the relevant market, then by combining the indicators of the concentration of supply and subjective grade to make conclusions which will be used in our case when defining budgetary assets for the needs of procurements in the defence system. 
Analysing the effect of raw cow milk purchase concentration on the Serbian market, it's evident that "Imlek" has undoubtedly leading role and that it represents a leader on this market, whose share on this relevant market is (/30-40/\%). All remaining competitors (dairies) have significant lower market shares than "Imlek" and raw milk purchase market that is characterized by fragmented, atomized market structure and very low market concentration level, it can be said that it has a monopoly which can be used to secure favorable position when offering its products as a supplier.

Резултати тржишта би се користили ради унапређења поступака набавки, а то би узрочно-последично водило ефикаснијој реализацији буџета одбране и обезбеђивању одговарајућег нивоа оперативних способности јединица Војске Србије

Results of thus coordinated analysis of the market would be used for promoting procurement procedure, which would by casual effect lead to more efficient realization of the budget of the defence system and securing a suitable level of operational capabilities of Serbian Army's units.

\section{Literature}

1. Amato, H., L., Wilder, P., R. (2004): Global competition andglobal markets: some empirical results, International Business Review, Vol. 13, No. 1, pp. 411-424, Elsevier, Amsterdam, Netherland.

2. Dobre, C. (2009): Measuring Market Concentracion According to European Competition Policy, Constanta Maritime University's Annals, Vol. 18, No. 3, pp. 265-270, Romania.

3. Drašković, B., Rajković, Z., Kostić, D. (2010): Milk production in Serbia and position small farmers. Economics of Agriculture, Vol. 57, No. 4, pp. 529-541. Društvo agrarnih ekonomista, Beograd, Srbija.

4. Ezekiel, M. (2012): The Cobweb Theorem, Oxford Journal, Oxford University Press, Oxford, UK.

5. Gould, J. P., Ferguson, C. E. (1984): Microeconomic Theory, Ilinois, Théorie microéconomique, Pariz, France.

6. Krstić, S., Krstić, D. (2016): Uloga menadžmenta preduzeća u kriznim situacijama, Oditor, Belgrade, Vol. 2, No. 1, pp. 11-18

7. Kostić, M. (2008): Merenje koncentracije ponude grane, Ekonomski horizonti, Vol. 10, No. 1, 2008, pp. 89-108, Ekonomski fakultet, Kragujevac, Srbija.

8. Labus, M. (2008): Uporedna analiza relevantnog tržišta: koncept i primena, Ekonomika preduzeća, Vol. 56, No. 2, pp. 48-61, Savez ekonomista Srbije, Beograd, Srbija.

9. Lipczynski, J., Wilson, J. (2001): Industrial organization - An Analysis of Competitive Markets, PrenticeHall, Harlow, UK.

10. Mihajlović, M. (2016): Odnos menadžmenta preduzeća i korporativnog upravljanja, Oditor, Belgrade, Vol. 2, No. 1, pp. 4-10.

11. Mikhalkina, E., Maitah, M., Šrédl, K. (2015): Measuring Market Structures in the Dairy 
Market in the Czech Republic, Asian Social Science, Vol. 11, No. 21 pp. 306-315.

12. Milojević, I., Vukoje, A., Mihajlović, M. (2013): Accounting consolidation of the balance by the acquisition method, Ekonomika poljoprivrede, Vol. 60, No. 2, pp. 237-252, Društvo agrarnih ekonomista, Beograd, Srbija.

13. Mitrović, A., Knežević, S., Veličković, M (2015): Ratio analysis specifics of the family dairies'financial statements, Ekonomika poljoprivrede, Vol. 62, No. 4 , pp. 1061-1078, Društvo agrarnih ekonomista, Beograd, Srbija.

14. Rađenović, Ž.(2015): Uticaj politike konkurencije na državnu pomoć i javni sektor u okviru jednstvenog tržišta Evropske unije, Facta universitatis - series: Economics and Organization, Vol. 12, No. 1, pp. 83-95, Univerzitet u Nišu, Srbija.

15. Stojanović, B., Radivojević, V. (2008): Koncentracija ponude kao izraz nesavršenosti tržišta: primer nespecijalizovane trgovine na malo na tržištu grada Niša, Ekonomika preduzeća, Vol. 54, No. 6, pp. 327-338, Društvo ekonomista "Ekonomika", Niš, Srbija.

16. Šaj, O. (2005): Industrijska organizacija teorija i primena, (prevod), CID Ekonomski fakultet, Beograd, Srbija.

17. Štiglic, DŽ. (2013): Ekonomija javnog sektora, prevedeno delo, CID Ekonomski fakultet, Beogradu, Srbija.

18. Vukoje, A. (2013): Faktori egzistencije kao uslov stvaranja tržišne pozicije preduzeća, ODITOR, Vol. 1, No. 5, pp. 27-37, Centar za ekonomska i finansijska istraživanja, Beograd, Srbija.

19. Zakon o zaštiti konkurencije, (Sl. glasnik RS No. 51/2009 i 95/2013).

20. Zakon o javnim nabavkama, (,Sl. Glasnik RS“, No. 124/2012, 14/2015 i 68/2015).

21.Zekić, S., Mijić, K., Jakšić, D., Milenković, I. (2016): Profitability gap in the milk production chain: evidence from Serbia, Ekonomika poljoprivrede, Vol. 63, No. 2 , pp. 485-499, Društvo agrarnih ekonomista, Beograd, Srbija

22.Zhou, K.Z, Gao, G.Z., Yang, Z., Zhou, N. (2005): Developing strategic orientation in China: antecedents and consequences of market and innovation orientations, Journal of Business Research, Vol. 58, No. 8, pp. 1049-1058.

23. www.stat.gov.rs

24. www.mpzzs.gov.rs

25. www.kzk.org.rs

26. www.mod.gov.rs

27. www.gov.rs 
EKONOMSKA ANALIZA UTICAJA KONCENTRACIJE TRŽIŠTA MLEKA NA EFIKASNOST NABAVKI U SISTEMU ODBRANE

\section{Milan Mihajlovićc ${ }^{7}$ Snežana Krstič ${ }^{8}$, Slobodan Šegrt ${ }^{9}$, Dragana Pavlovićrio, Duško Jovanović ${ }^{11}$, Tihomir Simeunović ${ }^{12}$}

\section{Rezime}

Povećanje efikasnosti realizacije nabavki u sistemu odbrane nameće zahtev za analizom tržišta, kako bi se uočile sve njegove karakteristike i jednim sveobuhvatnim postupkom doneli zaključci koji su od koristi prilikom planiranja budžetskih sredstava. Nabavka mleka i mlečnih prozvoda predtstavlja značajan deo ukupnih nabavki sistema odbrane što ih čini $i$ važnim segmentom potrošačkog standarda Vojske Srbije, odakle sledi interesovanje autora da na primeru ovog tržišta ukažu na značaj koncentracije ponude grane za realizaciju nabavki. Cilj ovog rada je da prikaže stanje i aktuelne trendove na tržištu proizvodnje i prerade mleka, definiše metodološke okvir i ukaže na intenzitet i uslove konkurencije $i$ njihov uticaj na kriterijume nabavki, posebno cenu, u sistemu odbrane Republike Srbije.

Ključne reči: ekonomska analiza, koncentracija, tržište mleka, nabavke, sistem odbrane.

7 Milan Mihajlović, M.A., Univerzitet odbrane u Beogradu, Vojna akademija, Pavla Jurišića Šturma 33, 11000 Beograd, Srbija, Tel.: +381 64302 1951, E-mail: milan.mih83@gmail.com

8 Snežana Krstić, Ph.D., docent, Univerzitet odbrane u Beogradu, Vojna akademija, Pavla Jurišića Šturma 33, 11000 Beograd, Srbija.

9 Slobodan Šegrt, PhD., docent, Visoka škola za menadžment i ekonomiju, Karađorđeva ulica br. 52, 34000 Kragujevac, Srbija.

10 Dragana Pavlović, M.A., Fakultet za sporst i fizičko vaspitanje, Beograd, Blagoja Parovića 156, 11000 Beograd, Srbija.

11 Duško Jovanović, PhD, docent, Visoka škola za menadžment i ekonomiju, Karađorđeva Street no. 52, 34000 Kragujevac, Srbija..

12 Tihomir Simeunović, PhD, docent, Visoka škola za menadžment i ekonomiju, Karađorđeva Street no. 52, 34000 Kragujevac, Srbija.

EP 2016 (63) 3 (973-985) 